\title{
Infrequent V617F mutation of the JAK2 gene in myeloid leukemia and its absence in lymphoid malignancies in Japan
}

\author{
Naoki Mori ${ }^{1}$, Kentaro Yoshinaga ${ }^{1}$, Makiko Tada ${ }^{1,2}$, Yanhua Wang ${ }^{1}$, Masayuki Shiseki ${ }^{1}$ and Toshiko Motoji ${ }^{1}$ \\ ${ }^{1}$ Department of Hematology, Tokyo Women's Medical University, Tokyo, Japan. \\ ${ }^{2}$ Meiji Pharmaceutical University, Tokyo, Japan.
}

\begin{abstract}
A unique mutation of the JAK2 gene, V617F, has recently been identified in polycythemia vera, essential thrombocythemia and myeloid metaplasia with myelofibrosis. To determine the relevance of this mutation in other types of hematological neoplasms in Japan, we performed allele-specific polymerase chain reaction analysis on the JAK2 gene. The V617F mutation was detected in one out of 130 myeloid neoplasms, but in none of 114 lymphoid malignancies and four biphenotypic acute leukemias. Although a favorable chromosomal alteration $\mathrm{t}(8 ; 21)(\mathrm{q} 22 ; \mathrm{q} 22)$ was observed in one acute myeloid leukemia (AML) patient with the mutation, two courses of chemotherapy resulted in induction failure and short survival. Sequencing of JAK2 cDNA revealed expression of the mutant allele in the patient. The $\mathrm{V} 617 \mathrm{~F}$ mutation might play a role in the pathogenesis of certain AML cases.
\end{abstract}

Key words: JAK2 gene, V617F mutation, signal transduction, acute myeloid leukemia, lymphoid malignancies.

Received: June 1, 2007; Accepted: December 14, 2007.

Myeloproliferative disorders (MPD) comprise a heterogeneous group of diseases including chronic myelocytic leukemia (CML), polycythemia vera (PV), essential thrombocythemia (ET), and myeloid metaplasia with myelofibrosis (MMM). With the exception of CML, characterized by the Philadelphia chromosome and the $B C R-A B L$ fusion gene, genetic events causing these disorders have remained unidentified for a long time. The Janus kinase 2 (JAK2) gene encodes a tyrosine kinase involved in cytokine signal transduction. JAK phosphorylates cytoplasmic targets including signal transducers and activators of transcription (STAT). In hematological neoplasms, several chromosomal translocations involving the $J A K 2$ gene locus have been identified (Khwaja, 2006). Recently, a unique mutation of the JAK2 gene, $\mathrm{G}$ to $\mathrm{T}$ transversion at nucleotide 1849 resulting in valine to phenylalanine substitution at amino acid position $617(\mathrm{~V} 617 \mathrm{~F})$, has been identified in MPD (Baxter et al., 2005; James et al., 2005; Kralovics et al., 2005; Levine et al., 2005a). This mutation was present in most patients with PV and in half of the patients with ET and MMM. Since the V617F mutation is located in the $\mathrm{JH} 2$ negative regulatory domain of the JAK2 gene, it disrupts the auto-inhibitory activity of JAK2. In consequence, the mutation leads to constitutive tyrosine phosphorylation activity, promoting cytokine hypersensi-

Send correspondence to Naoki Mori. Department of Hematology, Tokyo Women's Medical University, 8-1 Kawada-cho, 162-8666 Shinjuku-ku, Tokyo, Japan. E-mail: mori@dh.twmu.ac.jp. tivity and inducing erythrocytosis in a mouse model (James et al., 2005).

Recent studies have shown the V617F mutation to be present in some cases of acute myeloid leukemia (AML), myelodysplastic syndrome (MDS) and chronic myelomonocytic leukemia (CMMoL) (Jelinek et al., 2005; Levine et al., 2005b). However, limited information is available to determine whether the mutation is specifically associated with myeloid neoplasms, and most of the studies are from Europe and North America. In order to assess the range and frequency of the mutation in Japanese patients with hematological neoplasms, we performed allelespecific polymerase chain reaction (PCR) analysis on the $J A K 2$ gene.

Bone marrow, peripheral blood or lymph node samples from 248 hematological neoplasms were analyzed after obtaining written informed consent (Table 1). Of the 248 samples, 130 were myeloid neoplasms, 114 were lymphoid neoplasms, and four were biphenotypic acute leukemias (BAL). The current study was conducted within the guidelines and with the approval of the institutional review board. The primer sequences for allele-specific PCR were previously published (Baxter et al., 2005):

ALLF-S， 5'-AGCATTTGGTTTTAAATTATGGA GTATATT-3';

ALLF-IC, 5'-ATCTATAGTCATGCTGAAAGTA GGAGAAAG-3'; and 
Table 1 - JAK2 V617F mutations in hematological neoplasms.

\begin{tabular}{|c|c|c|}
\hline & $\begin{array}{c}\text { Number of } \\
\text { samples }\end{array}$ & $\begin{array}{l}\text { Number of V617F } \\
\text { myeloid malignancies }\end{array}$ \\
\hline \multicolumn{3}{|l|}{ Myeloid malignancies } \\
\hline AML & 38 & 1 \\
\hline MDS & 38 & 0 \\
\hline RAEB- $t^{1}$ & 2 & 0 \\
\hline MDS/AML & 16 & 0 \\
\hline $\mathrm{CML} \mathrm{CP}^{2}$ & 18 & 0 \\
\hline $\mathrm{CML} \mathrm{AP}^{3}$ & 1 & 0 \\
\hline $\mathrm{CML} \mathrm{BC}^{4}$ & 11 & 0 \\
\hline CMMoL & 5 & 0 \\
\hline $\mathrm{aCML}^{5}$ & 1 & 0 \\
\hline \multicolumn{3}{|c|}{ Lymphoid malignancies } \\
\hline MM & 48 & 0 \\
\hline MGUS $^{6}$ & 2 & 0 \\
\hline ALL & 40 & 0 \\
\hline CLL & 7 & 0 \\
\hline ML & 8 & 0 \\
\hline Macroglobulinemia & 2 & 0 \\
\hline ATL & 7 & 0 \\
\hline $\begin{array}{l}\text { Biphenotypic acute } \\
\text { leukemia }\end{array}$ & 4 & 0 \\
\hline Total & 248 & 1 \\
\hline
\end{tabular}

${ }^{1}$ RAEB-t, refractory anemia with excess of blasts in transformation; ${ }^{2} \mathrm{CP}$, chronic phase; ${ }^{3} \mathrm{AP}$, accelerated phase; ${ }^{4} \mathrm{BC}$, blast crisis; ${ }^{5} \mathrm{aCML}$, atypical chronic myeloid leukemia; ${ }^{6} \mathrm{MGUS}$, monoclonal gammopathy with undetermined significance.

\section{ALLR-S， 5'-CTGAATAGTCCTACAGTGTTTTC} AGTTTCA-3'.

ALLF-S is specific for the mutant allele and contains an intentional mismatch at the third nucleotide from the 3 ' end, to improve specificity. After $5 \mathrm{~min}$ at $94^{\circ} \mathrm{C}, 36$ amplification cycles of $60 \mathrm{~s}$ at $94{ }^{\circ} \mathrm{C}, 60 \mathrm{~s}$ at $58^{\circ} \mathrm{C}$ and $60 \mathrm{~s}$ at $72{ }^{\circ} \mathrm{C}$ were performed, with a subsequent 7 min extension at $72^{\circ} \mathrm{C}$. Electrophoresis was repeated two or three times in each sample, using independent PCR products. Primers ALLF-S and ALLR-S amplify 203-bp (base pair) products, while the size of products using primers ALLF-IC and ALLR-S is $364 \mathrm{bp}$. The 203-bp products indicated the V617F mutation, while the 364-bp products indicated the internal control. PV samples with the V617F mutation were used as positive control. Aberrant bands were detected in one of the 248 samples (AML02, Figure 1 lane 5).

To confirm the aberrant bands detected by allelespecific PCR, DNA from AML02 was subsequently sequenced in both directions on a MegaBase sequence system (Amersham, Buckingham, UK). PCR products were purified and ligated into pGEM-T vector (Promega, Madison, WI, USA). Sequencing revealed G to $\mathrm{T}$ transversion at nucleotide 1849, resulting in the V617F mutation (Figure 2). Several samples without aberrant bands by allele-specific

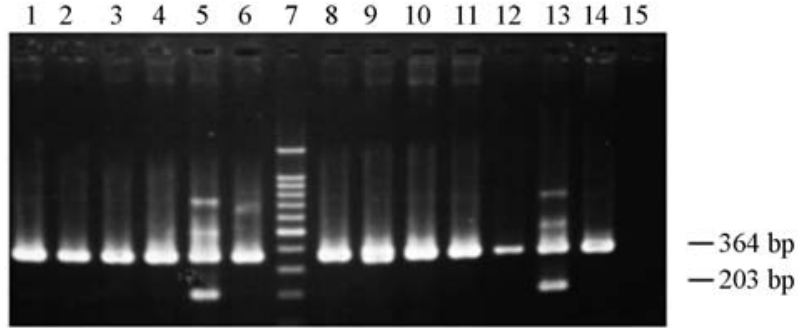

Figure 1 - Allele-specific PCR analysis of the $J A K 2$ gene in hematological neoplasms. Ten of $20 \mu \mathrm{L}$ of PCR products were separated by electrophoresis on $2 \%$ agarose gel, stained with ethidium bromide and visualized by ultraviolet illumination. The size of the products is indicated on the right. Aberrant bands were detected in one of the AML samples (lane 5). Lane 1, AML01; lane 2, MDS01; lane 3, ALL01; lane 4, BAL01; lane 5, AML02; lane 6, AML03; lane 7, 100 bp ladder; Lane 8, ALL02; lane 9, AML04; lane 10, AML05; lane 11, AML06; lane 12, CLL01, lane 13, PV01; lane 14, CML01, lane 15, water. Aberrant bands of PV01 are shown as positive control (lane 13).

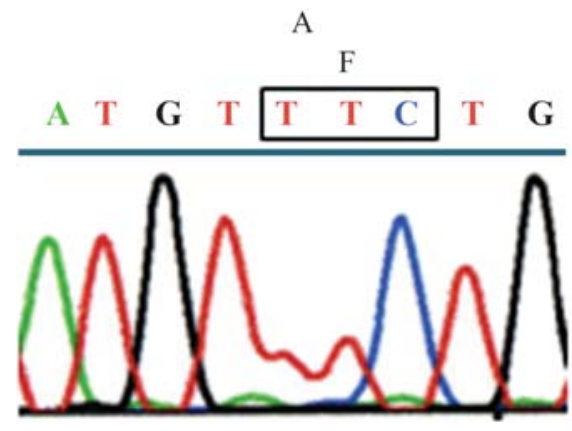

B
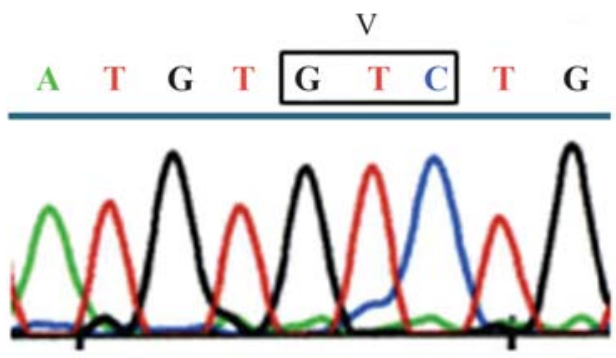

Figure 2 - Sequence analysis of the $J A K 2$ gene in AML. Sequencing identified $\mathrm{G}$ to $\mathrm{T}$ transversion at nucleotide 1849 , resulting in the V617F mutation in the AML sample (A, AML02). Wild-type sequences are shown as control (B, MM01)

PCR were also sequenced, but only wild-type sequences were obtained.

To determine the expression of the JAK2 V617F mutation, we performed reverse transcriptase-PCR (RT-PCR) analysis in AML02 (Mori et al., 1990). The following sequences were used for the primers: RT-11F1, 5'-AAAGC CTTGGCCAAGGCACTT-3'; and RT-13R2, 5'-ATGCA TGGCCCATGCCAACTG-3'. After 5 min at $94{ }^{\circ} \mathrm{C}, 30$ amplification cycles of $60 \mathrm{~s}$ at $94^{\circ} \mathrm{C}, 60 \mathrm{~s}$ at $55^{\circ} \mathrm{C}$ and $60 \mathrm{~s}$ at $72{ }^{\circ} \mathrm{C}$ were performed, with a subsequent 10 min extension at $72{ }^{\circ} \mathrm{C}$. Primers RT-11F1 and RT-13R2 amplify 
340 -bp products. Sequencing of $J A K 2$ cDNA revealed the expression of the mutant allele in 20 out of 41 AML02 clones.

The V617F mutation of the $J A K 2$ gene was found in one of the 130 myeloid neoplasms, but not in the 114 lymphoid malignancies or in the four biphenotypic acute leukemias. The mutation was detected in the majority of Japanese patients with PV and ET (K Yoshinaga, N Mori, Y Wang, M Shiseki, T Motoji, unpublished data). In contrast to classic MPD, the V617F mutation was infrequent in myeloid leukemia and absent in lymphoid malignancies. Recent reports show that the JAK2 V617F mutation was not identified in either acute lymphoblastic leukemia (ALL) or chronic lymphocytic leukemia (CLL) (Levine et al., 2005b). Our study showed that also in Japan the V617F mutation is absent in ALL and CLL. Furthermore, it was also undetectable in adult T-cell leukemia (ATL), macroglobulinemia, multiple myeloma (MM), and malignant lymphoma (ML).

AML02 was obtained from a patient with AML showing M2 morphology according to the French-American-British (FAB) classification at diagnosis. This patient was a 70-year-old woman with no history of preceding MPD or MDS. Peripheral blood tests revealed $50.1 \times 10^{9} / \mathrm{L}$ leukocytes with $76.5 \%$ blast cells, $7.8 \mathrm{~g} / \mathrm{dL}$ hemoglobin, and $55 \times 10^{9} / \mathrm{L}$ platelets. Although the favorable chromosomal alteration $\mathrm{t}(8 ; 21)(\mathrm{q} 22 ; \mathrm{q} 22)$ accompanied by AML1/ETO transcripts was the only chromosomal abnormality observed in the patient, two courses of chemotherapy resulted in induction failure and short survival. The mutation was found in nine out of 14 AML02 clones. Since this sample was expected to contain more than $90 \%$ blast cells after mononuclear cell isolation, this case may have been heterozygous for the V617F mutation. Another possibility is that a substantial proportion of the leukemic cells from AML02 did not harbor the mutation.

The V617F mutation was detected in one of the 38 patients with AML (3\%). Other recent studies found a similar incidence of the V617F mutation: 0/17 (Jones et al., 2005), 5/90 (6\%) (Scott et al., 2005), 2/39 (5\%) (Jelinek et al., 2005), 4/222 (2\%, three had preceding MPD) (Levine et al., 2005b), 1/152 (0.7\%) (Frohling et al., 2006), and 2/112 (2\%) (Lee et al., 2006). The V617F mutation in AML was initially found in FAB M6 (1/53) (Frohling et al., 2006) and FAB M7 (2/11) (Jelinek et al., 2005), while the FAB subtype of AML was not described in other reports. In the current study, this mutation was also found to be present in one out of 12 patients with AML M2 (8\%): one of the four patients with $\mathrm{t}(8 ; 21)$ (q22;q22). After submission of our paper, expression of the JAK2 V617F mutation was reported in two out of $18 \mathrm{MDS} / \mathrm{AML}$ but not in 198 de novo AML cases (Nishii et al., 2007). In contrast to their result, in the present study expression of the mutant allele was detected in AML02, as described above.
Our study revealed that the V617F mutation is infrequent in myeloid leukemia and absent in lymphoid malignancies in Japan. Nevertheless, it was detected in AML02, along with the favorable cytogenetic alteration $\mathrm{t}(8 ; 21)(\mathrm{q} 22 ; \mathrm{q} 22)$. Previous studies have demonstrated that additional event(s) are required for the development of AML in the presence of $\mathrm{t}(8 ; 21)(\mathrm{q} 22 ; \mathrm{q} 22)$ (Yuan et al., 2001; Kuchenbauer et al., 2006). Tyrosine kinases have been involved in several disorders including BCR-ABL in CML, PDGFR $\beta$ in CMMoL, and PDGFR $\alpha$ in chronic eosinophilic leukemia. Furthermore, activating mutations in the FLT3 receptor tyrosine kinase gene are the most common genetic events in AML. Patients with FLT3 mutations have a poor prognosis, suggesting the important role of tyrosine kinase gene mutations in leukemogenesis. The relation between the V617F mutation and short survival in AML02 is unclear. The V617F mutation might confer a proliferative advantage to blast cells and play a role in the pathogenesis of certain AML cases. As suggested for FLT3 mutations, constitutive signaling in the absence of ligand may result in reduced apoptosis of the leukemic cells or may grant increased repair capacity following cell damage; either of these mechanisms could be considered as inducing chemoresistance (Kottaridis et al., 2001). Further studies will clarify the incidence and significance of the V617F mutation in AML with $\mathrm{t}(8 ; 21)(\mathrm{q} 22 ; \mathrm{q} 22)$.

\section{References}

Baxter EJ, Scott LM, Campbell PJ, East C, Fourouclas N, Swanton S, Vassiliou GS, Bench AJ, Boyd EM, Curtin N et al. (2005) Acquired mutation of the tyrosine kinase JAK2 in human myeloproliferative disorders. Lancet 365:10541061.

Frohling S, Lipka DB, Kayser S, Scholl C, Schlenk RF, Dohner H, Gilliland DG, Levine RL and Dohner K (2006) Rare occurrence of the JAK2 V617F mutation in AML subtypes M5, M6, and M7. Blood 107:1242-1243.

James C, Ugo V, Le Couédic J-P, Staerk J, Delhommeau F, Lacout C, Garçon L, Raslova H, Berger R, BennaceurGriscelli A et al. (2005) A unique clonal JAK2 mutation leading to constitutive signaling causes polycythaemia vera. Nature 434:1144-1148.

Jelinek J, Oki Y, Gharibyan V, Bueso-Ramos C, Prchal JT, Verstovsek S, Beran M, Estey E, Kantarjian HM and Issa J-PJ (2005) JAK2 mutation $1849 \mathrm{G}>\mathrm{T}$ is rare in acute leukemias but can be found in CMML, Philadelphia chromosome-negative CML, and megakaryocytic leukemia. Blood 106:3370-3373.

Jones AV, Kreil S, Zoi K, Waghorn K, Curtis C, Zhang L, Score J, Seear R, Chase AJ, Grand FH et al. (2005) Widespread occurrence of the JAK2 V617F mutation in chronic myeloproliferative disorders. Blood 106:2162-2168.

Khwaja A (2006) The role of Janus kinases in haemopoiesis and haematological malignancy. Br J Haematol 134:366-384.

Kottaridis PD, Gale RE, Frew ME, Harrison G, Langabeer SE, Belton AA, Walker H, Wheatley K, Bowen DT, Burnett AK et al. (2001) The presence of a FLT3 internal tandem dupli- 
cation in patients with acute myeloid leukemia (AML) adds important prognostic information to cytogenetic risk group and response to the first cycle of chemotherapy: Analysis of 854 patients from the United Kingdom Medical Research Council AML 10 and 12 trials. Blood 98:1752-1759.

Kralovics R, Passamonti F, Buser AS, Teo S-S, Tiedt R, Passweg JR, Tichelli A, Cazzola M and Skoda RC (2005) A gainof-function mutation of $J A K 2$ in myeloproliferative disorders. N Engl J Med 352:1779-1790.

Kuchenbauer FS, Schnittger L, Look T, Gilliland G, Tenen D, Haferlach T, Hiddemann W, Buske C and Schoch C (2006) Identification of additional cytogenetic and molecular genetic abnormalities in acute myeloid leukaemia with $\mathrm{t}(8 ; 21) / A M L 1-E T O$. Br J Haematol 134:616-619.

Lee JW, Kim YG, Soung YH, Han KJ, Kim SY, Rhim HS, Min WS, Nam SW, Park WS, Lee JY et al. (2006) The JAK2 V617F mutation in de novo acute myelogenous leukemias. Oncogene 25:1434-1436.

Levine RL, Wadleigh M, Cools J, Ebert BL, Wernig G, Huntly BJP, Boggan TJ, Wlodarska I, Clark JJ, Moore S et al. (2005a) Activating mutation in the tyrosine kinase JAK2 in polycythemia vera, essential thrombocythemia, and myeloid metaplasia with myelofibrosis. Cancer Cell 7:387-397.

Levine RL, Loriaux M, Huntly BJ, Loh ML, Beran M, Stofferegen E, Berger R, Clark JJ, Willis SG, Nguyen KT et al. (2005b) The JAK2 V617F activating mutation occurs in chronic myelomonocytic leukemia and acute myeloid leukemia, but not in acute lymphoblastic leukemia or chronic lymphocytic leukemia. Blood 106:3377-3379.

Mori N, Yokota J, Akiyama T, Sameshima Y, Okamoto A, Mizoguchi H, Toyoshima K, Sugimura T and Terada M (1990) Variable mutations of the $R B$ gene in small-cell lung carcinoma. Oncogene 5:1713-1717.

Nishii K, Nanbu R, Lorenzo FV, Monma F, Kato K, Ryuu H and Katayama N (2007) Expression of the JAK2 V617F mutation is not found in de novo AML and MDS but is detected in MDS-derived leukemia of megakaryoblastic nature. Leukemia 21:1337-1338.

Scott LM, Campbell PJ, Baxter EJ, Todd T, Stephens P, Edkins S, Wooster R, Stratton MR, Futreal PA and Green AR (2005) The V617F JAK2 mutation is uncommon in cancers and in myeloid malignancies other than the classic myeloproliferative disorders. Blood 106:2920-2921.

Yuan Y, Zhou L, Miyamoto T, Iwasaki H, Harakawa N and Hetherington CJ (2001) AML1-ETO expression is directly involved in the development of acute myeloid leukemia in the presence of additional mutations. Proc Natl Acad Sci USA 98:10398-10403.

\section{Associate Editor: Emmanuel Dias Neto}

License information: This is an open-access article distributed under the terms of the Creative Commons Attribution License, which permits unrestricted use, distribution, and reproduction in any medium, provided the original work is properly cited. 